ISSN 1112-9867

Available online at http://www.jfas.info

\title{
INVENTORY OF ARTHROPODS ON SESBANIA ACUELATA IN THE ALGERIAN SAHARA AND QUANTIFICATION OF PHENOLIC COMPOUNDS BY HPLC
}

\author{
I. Larkem $^{1 *}$, N. Benchikha ${ }^{2}$, S. Domandji ${ }^{1}$, M. B. Domandji ${ }^{1}$
}

${ }^{1}$ National superior school of agronomics, Department of Agricultural Zoology and Forestry Algiers, Algeria

${ }^{2}$ University of El Oued, Department of Chemistry B.P 789 El Oued, Algeria

Received: 23 Mars 2017 / Accepted: 20 August 2017 / Published online: 01 September 2017

\begin{abstract}
The present study was carried out at the I.T.D.A.S. (Biskra). It contributes to the inventory and knowledge of arthropods which are successfully infecting a plant newly introduced in Algeria in this case Sesbania acuelata. During the summer of 2016, each month, arthropods are collected using three methods: pitful traps, yellow water traps and direct hunting. The survey resulted in the retrieval of 685 individuals in 125 arthropods, grouped into 66 families and 13 orders. The results thus obtained showed a predominance of the order Hymenoptera followed by Diptera and Orthoptera. The Order of the acari is the least represented. For a better qualitative and quantitative analysis of the species identified, numerous ecological indices were used.

The extract obtained was analyzed, under optimum conditions, by HPLC which allowed the identification of seven phenolic compounds which are ascorbic acid, gallic acid, chlorogenic acid, caffeic acid, and Vanillin, quercitin, rutin acids. Sesbania acuelata, can be, however, considered as a plant of pharmaceutical utility of great importance in addition to the other virtues.
\end{abstract}

Key words: Inventory, Arthropods, Sesbania acuelata, phénolic compounds, HPLC

Author Correspondence, e-mail: i.larkem@st.ensa.dz

doi: http://dx.doi.org/10.4314/jfas.v9i3.20 


\section{INTRODUCTION}

The severe pedoclimatic conditions in the south of Algeria, mainly high temperatures, sand winds, soil and water salinity, lead to low yields in forage crops. The work carried out at the ITDAS station is to introduce a new forage plant in this case "Sesbania aculeata" which combines both hardiness and high yield.

The scientific community agrees to highlight the importance of Arthropods [1] especially insects that account for about half of living species. In desert regions, their presence is reported in a broad thermal spectrum, where the contrasting temperatures between seasons and between day and night are extremely high [2]. Plants are primary producers (Autotroph) and arthropods are Heterotrophic. These arthropods represent groups strongly dependent on available energy. They are diversified and ecologically very important, making a presence in all terrestrial ecosystems [3], 46\% of which feed on plants [4].

The present work comes in the form of a study devoted to the arthropodological fauna and the quantification of the polyphenols present in our plant Sesbania acuelata. First part of this study is to establish an inventory as complete as possible of arthropods attracted by Sesbania acuelata. The second part is to study the effect of phenolic compounds, after analysis, on the dynamic of Arthropods Associated with this plant.

\section{MATERIAL AND METHODS}

\subsection{Location of the study area}

ITDAS (TECHNICAL INSTITUTE FOR THE DEVELOPMENT OF SAHARAN AGRONOMY) is located in the Region of ZIBAN (BISKRA) whose coordinates are $5^{\circ} 65^{\prime} 6^{\prime \prime}$, the Longitude and $34^{\circ} 93^{\prime} 6^{\prime}$ ' of latitude with an altitude of 207 meters.

Located north of région of Biskra, the station is a plain with a clay soil with smooth texture undrained. This is a demonstration and seed production farm with an area of 40 ha. The crops grown on the experimental site include olive trees (3ha), vines (1ha), alfalfa (1.5ha), cereals (1ha), greenhouse crops (0.5ha), pistachio (1/3ha), pear ( 1 / 3ha), and a ( 1 / 3ha) space for the testing of Sesbania and Quinoas for applied research with the aim of developing Saharan agriculture [5].

\subsection{Sampling methods of arthropods}

Arthropods were sampled using three methods; pitfall traps [Fig.1a], yellow colored traps [Fig.1b] and hunting sight. The applied experimental device has 64 traps installed in the cultivated plot of Sesbania acuelata throughout the sampling period 
The species caught by the interception traps, the yellow and hand plates are brought back to the laboratory of Zoology Agricultural and Forestry of the National Agricultural Superior School to determine them. This operation is carried out in particular by Professor Doumandji Salaheddine, using the keys of determination of the Coleoptera (PERRIER, 1927), Hymenoptes (PERRIER, 1940), Orthopteroids (CHOPARD, 1943) and Diptera (PERRIER ,1983) And (MATILE, 1993 and 1995).
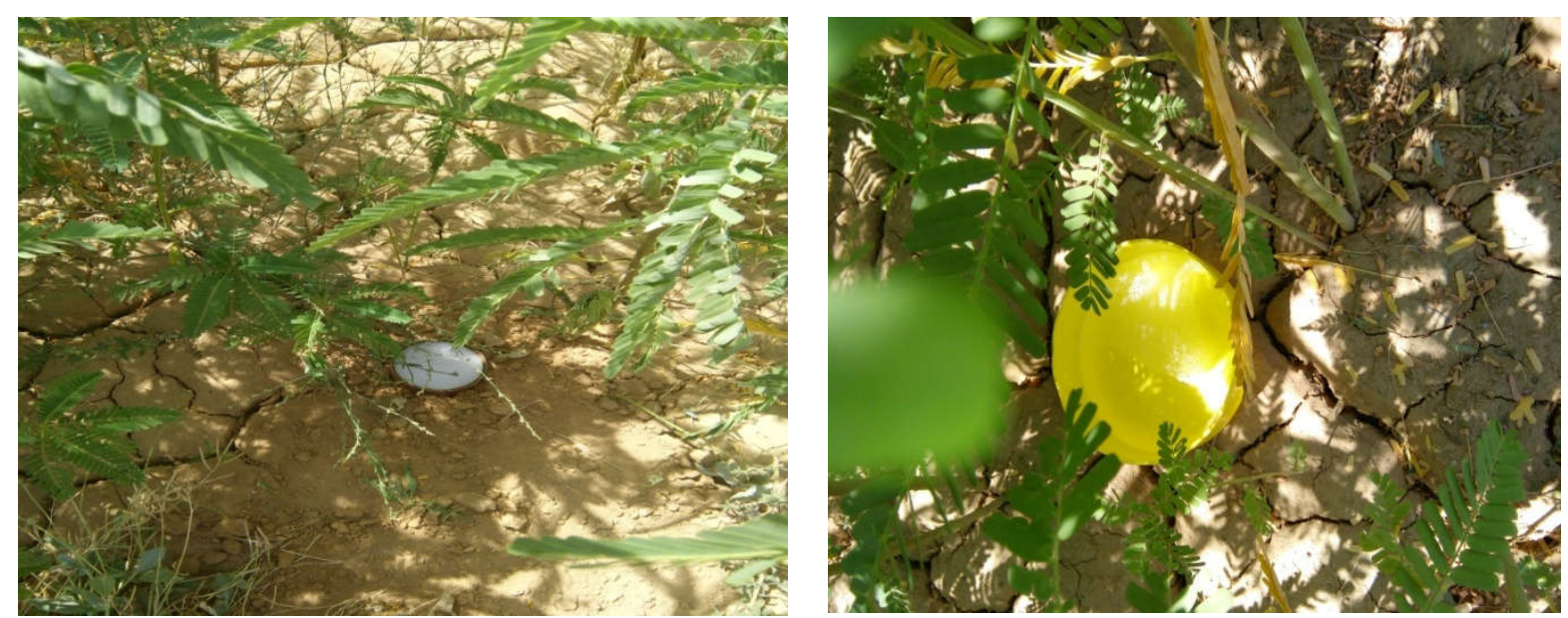

Fig.1. Methods used for sampling arthropods

\section{Chemicals:}

All chemicals were of analytical grade solvent for the extraction, ethanol were purchased from Sigma Aldrich (france). Gallic, vanillic, ascobic and chlogenic acids, rutin and quercitin were acquired from Sigma chemical

\section{Soxhlet extraction procedure}

$10 \mathrm{~g}$ of dried leaves of Sesbania acuelata and $150 \mathrm{ml}$ of solvent (ethanol) were refluxed by $6 \mathrm{~h}$ using soxhlet apparatus. The extract was filtred concentrated until dryness. The experiment was performed in triplicate

\subsection{HPLC analysis of extract}

HPLC analysis of the leaves extract and standards were performed on shimadzu_RP_HPLC about $20 \mu \mathrm{l}$ of analyte solution was injected into HPLC valve using a puradisc $25 \mathrm{~mm}$ and terumo syringe $(5 \mathrm{cc} / \mathrm{ml})$ at room temperature. Phenolic compounds were separated on a thermo scientific (HPLC_RP_18), column CTO-20AC (250mm x 4,6mm) packed with $\mathrm{C}_{18}$ stationary phase with particle size of $5 \mu \mathrm{m}$ at rate $1 \mathrm{ml} / \mathrm{min}$. the binary mobile phase consisted of a solvent A (water, acetic acid 0,2\%) detected by UV-SPD-20A at wave length $300 \mathrm{~nm}$. The chromatographic peaks were identified by comparing retention time of analysis with 
compound that of reference compounds High performance liquid chromatography is probably the most widely used analytical technique for characterizing the polyphenolic individual compounds [6].This technique is used for the qualitative analysis of ethanolic extract of the leaves of sesbania acuelata taken from Biskra area. All tests were performed in triplicate.

\section{RESULTS AND DISCUSSION}

The overall inventory of all arthropod species caught during the experimentation, allowed us to identify species belonging to classes; Insecta class, Arachnida class and collombola and crustacea classes, Table.1(see the end of the paper).

The total inventory of arthropod species caught at ITIDAS during the summer of 2016 by the three sampling methods is 685 individuals representing 125 arthropod species grouped into 66 families, 13 orders, and 4 classes, which are the Arachnida, the Collembola, the Crustacea and the Insecta class.

The results thus obtained showed a predominance of the order of Hymenoptera with 28 species covering 13 different families followed by Diptera and Orthoptera, in second place, with 24 and 16 species. Orhoptera and Homoptera were respectively with 9 and 7 species followed by Hemiptera with 5 species. Other orders were very poor in species ( 1 or 2 species for each).

HPLC analysis was employed to identify and quantify the major polyphenolic compounds contained in Sesbania acuelata. The retention time, equation of calibration curve and correlation coefficient from standards were reported in table 2.

Table 2. Standards Parameters of HPLC-UV

\begin{tabular}{|l|c|l|l|}
\hline \multicolumn{1}{|c|}{ Compounds } & $\begin{array}{c}\text { Retention time } \\
\text { (min) }\end{array}$ & \multicolumn{1}{|c|}{$\begin{array}{c}\text { Equation of the } \\
\text { calibration curve }\end{array}$} & $\begin{array}{c}\text { correlation } \\
\text { Coefficient }\end{array}$ \\
\hline 1- Ascorbic acid & 4.32 & $\mathrm{Y}=211.7 \mathrm{x}+1098$ & $\mathrm{R}^{2}=0.9614$ \\
\hline 2- Gallic acid & 5.25 & $\mathrm{Y}=23616 \mathrm{x}-7232$ & $\mathrm{R}^{2}=0.9984$ \\
\hline 3- Chlorogenic acid & 13.63 & $\mathrm{Y}=39775 \mathrm{x}-181$ & $\mathrm{R}^{2}=0.9983$ \\
\hline 4- Caffeic acid & 16.35 & $\mathrm{Y}=72328 \mathrm{x}$ & $\mathrm{R}^{2}=0.9986$ \\
\hline 5-Vanillic acid & 21.58 & $\mathrm{Y}=82773 \mathrm{x}-1423$ & $\mathrm{R}^{2}=0.9984$ \\
\hline 6- Quercetin & 20.50 & $\mathrm{Y}=548,0 \mathrm{x}-2832$ & $\mathrm{R}^{2}=0.996$ \\
\hline 7- Rutin & 29.046 & $\mathrm{Y}=24112.98 \mathrm{x}-1060$ & $\mathrm{R}^{2}=0.995$ \\
\hline
\end{tabular}


The results of qualitative analysis of HPLC showed that various phenolic acids (five) and two flavonoids were identified (table 3 ).

Table 3. Phenolic compound identified by HPLC analysis from Sesbania acuelata extract

\begin{tabular}{|l|c|}
\hline \multicolumn{1}{|c|}{ Compounds } & Concentration \\
& $\mu \mathrm{g} / \mathrm{mg}$ \\
\hline Ascorbic acid & 78.50 \\
\hline Gallic acid & 1.556 \\
\hline Chlorogenic acid & 2.99 \\
\hline Caffeic acid & 0.381 \\
\hline Vanillin acid & 0.065 \\
\hline Quercetin & 24.168 \\
\hline Rutin & 0.266 \\
\hline
\end{tabular}

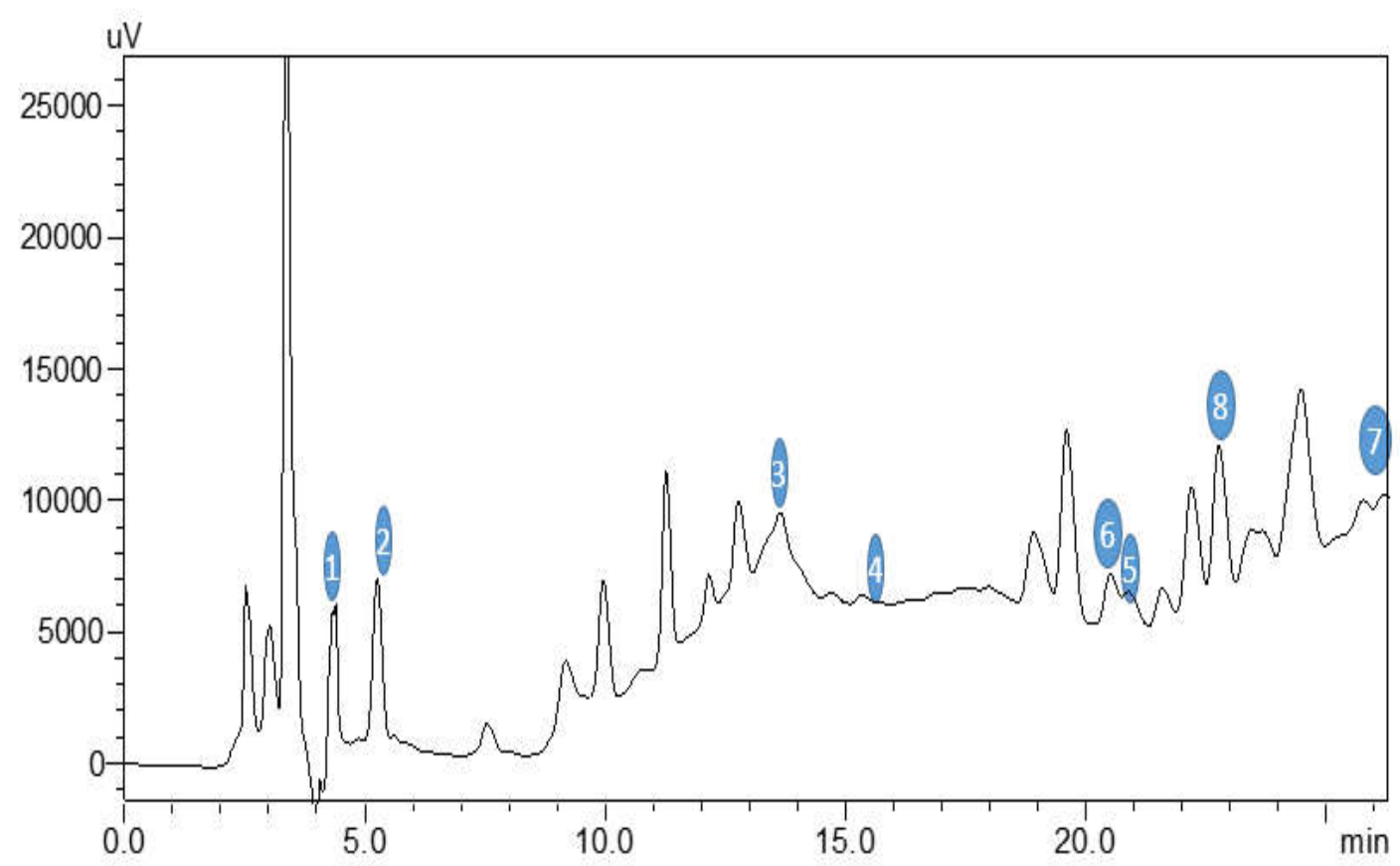

Fig.1. Chromatogram (HPLC-UV) of ethanolic extract of Sesbania acuelata leaves

Figure 2 presents the chromatographic profile (HPLC-UV) of ethanolic extract of Sesbania acuelata obtained by soxhlet apparatus.

The Peaks 1, 2, 3, 4, 5, 6 and 7 were positively identified as ascorbic acid, gallic acid, chlorogenic acid, caffeic acid quercitin, vanillic acid rutin respectively, by comparing the 
retention time, absorption and mass spectra with those of standards various phenolic acids and flavonoids in Sesbanian acuelata concentration in the extraction solution can be calculated from its peaks area to be $4 \mathrm{mg} / \mathrm{ml}$.

\subsection{Treatment of results by ecological indices}

\subsubsection{The sampling quality}

The sampling quality of arthropods caught on Sesbania acuelata at the ITIDAS station during the summer season indicate a value wich is close to zero $(0.10)$, it shows that the sampling is relatively good quality and that the inventory is carried out with sufficient accuracy. Good sampling quality may also be related to the high number of traps and the diversity of trapping methods. In general, species caught only once are very limited. The absence of host plants or prey of these species in the study area may partly explain their rarity [7].

\section{The average richness}

The average wealth was equal to 1,95 wich is low, this seems to be due to that Insects can maintain their metabolic activities only within a limited range of body temperatures. They can escape unfavorable thermal conditions by settling in areas with favorable micro-climates [8]

\subsubsection{Relative Abundance}

The different type of traps captured 685 individuals of arthropods répartited into 4 classes. The class of Insect was the most dominant.

According to the orders, the Hymenoptera is the most abundant order with $38 \%$. We find in second position Diptera and Orthoptera with respectevly 19\%, 14\%. The Coleoptera order with $11 \%$ in the third place [Fig.3].

The important presence of these orders in our traps may be due to the characteristics of our flowering plant that promotes maintenance and the spread of several species 


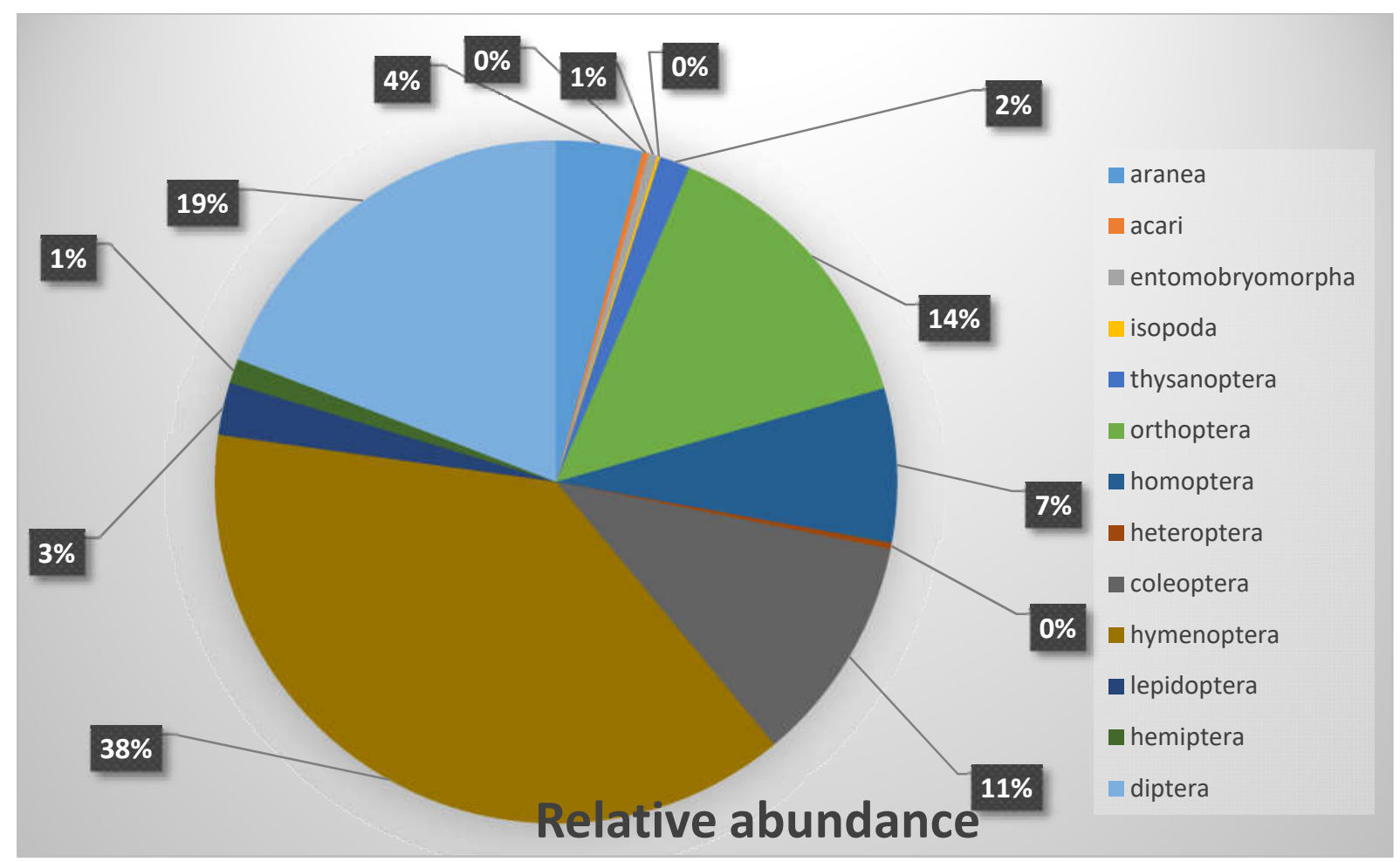

Fig.3. Relative abundances of the orders listed on Sesbania acuelata in ITIDAS Biskra

Many nitrogen-fixing plants, for several centuries, have been used as green manure, notably in Asia. Legumes, such as Aeschynomene americana, A. indica. Astrauglus sinicug, M. officinalis, Sesbania aculeata, S. mnnabina, S, Daludosa. Vicia cracca [9]

Sesbania aculeata is a seasonal leguminous weed of Northern Orissa. Its green fodder and DM yield were 136.05 and $36.37 \mathrm{q} /$ ha, respectively [10-12].

This study aims to quantify the arthropods that will be attracted on Sesbania, as well as its chemical composition.

The total inventory of arthropod species caught at ITIDAS during the summer of 2016 by the three sampling methods is 685 individuals representing 125 arthropod species grouped into 66 families, 13 orders, and 4 classes, which are the Arachnida, the Collembola, the Crustacea and the Insecta class.

It can be noted that the results obtained in this study are almost identical to those of Deghiche-Diab. The inventory of arthropods carried out by the latter in the palm groves of Ain Ben Noui, Ouled Djellel, Sidi Okba and El Kantara made it possible to draw up a systematic list of 195 taxon distributed over 4 classes [13-14].

That of Insects with 174 species, that of the Arachnids with 19 species and that of the Chilopoda and Malacostraca with one species for each species. The entomological species 
listed are divided into 13 orders belonging to the class of insects of which the Coleoptera is best represented with 54 species covering 16 different families. The order Lepidoptera isrepresented with 31 species and 11 families. On the other hand, they are significantly better than those obtained by Achora and Belhamra in (2010), who moved a wealth of 48 taxas in two palm groves in El Kantara [12].

Overall, it can be noted that Sesbania aculeata did not exert a particular effect on the distribution of entomofauna in Biskra.

\section{CONCLUSION}

In conclusion, this study indicates that the extract obtained from the leaves of Sesbania acuelata from Biskra area is a potential source of natural antioxidants. This study allowed us too to establish a list of entomological biodiversity present on a plant Sesbania acuelata newly introduced in Algéria. This basic list may be a reference for Complementary studies to be carried out subsequently to study the evolution of the biodiversity of this plant in the Algerian sahara .

\section{REFERENCES}

1- Sahu B.K., Panda S.K., Panda N.C. 1988 : Yield, Chemical Composition and Nutritive Value of Banicha (Sesbania Aculeata) Fodder for Goats Indian Journal of Animal Nutrition.Volume : 5 , Issue : 1 ,61-63.

2- Patnaik, S. and Rao, M.V. (1979). In Nitrogen and Rice: Sources of nitrogen for rice production, 25-43. International Rice Research Institute, Los Baños, Philippines. 15. Schaede, R. (1940). Planta 21-21.

3- Blackman R.L. et Eastop V.F. 2000. Aphids on the World's Crops. An identification and information guide. Ed. Ltd JWS and Natural History Museum, London, 466p.

4- Lebreton J.D Décamps H. et Douce R. 2013. La biodiversité, Livret sur l'environnement. Institut de France. Académie des sciences. 11p.

5- Daly H.V. Doyen J.T. et Purcell A.H. 1998. Introduction to insect biology and diversity, 2nd ed. oxford university press, Oxford, New York.

6- Kergoate G J. 2004. Genre Bruchidius (Coleoptera, Bruchidae): un modèle pour l'étude des relations évolutives entre les insectes et les plantes. Thèse Doctorat en Biologie. Université Paris 6-Pierre et Marie Curie. 201p.

7- ITIDAS ; institut technique de développement et de l'agriculture saharienne.2013 
8- Dajoz R. Précis d'écologie. 7ème édition, Ed. Dunod, Paris, 2003, 615.

9- Gómez-Caravaca AM, Gómez-Romero M, Arráez-Román D, Segura-Carretero A, Fernández-Gutiérrez A. (2006). Advances in the analysis of phenolic compounds in products derived from bees.Journal of Pharmaceutical and Biomedical Analysis, 41, 1220 1234.PMid:16621403.

10- Achoura A. ET Belhamra M. 2010. Aperçu sur la faune Arthropodologique des palmeraies d'El-Kantara université Mohamed Khider Biskra. Courrier Savoir. 10 (93101).

11-Deghiche- Diab Nacima 2016: Etude de la biodiversité des arthropodes et des plantes spontanées dans l'agro-écosystème oasien, Magister en sciences agronmiques UNIVERSITE MOHAMED KHIDER BISKRA,94p

12-Duelli P. 1997. Biodiversity evaluation in agricultural landscapes: an approach at two different scales, Agriculture Ecosystems and Environment, 62 (81-91).

13- Duelli P. et Obrist M.K. 1998. In search of the best correlates for local organismal biodiversity in cultivated areas, Biodiversity and Conservation. 7 (297-309).

14- Calatayud P.A. 2011. Interactionsplantes-insectes. Habilitation

DirigerdesRecherches(HDR). UniversitéParis Sud11. 86p.

How to cite this article:

Larkem I, Benchikha N, Domandji S, Domandji MB. Inventory of arthropods on sesbania acuelata in the algerian sahara and quantification of phenolic compounds by HPLC. J. Fundam. Appl. Sci., 2017, 9(3), 1569-1584. 
Table1.Global inventory of arthropods caughted on Sesbania acuelata

\begin{tabular}{|c|c|c|c|c|}
\hline Classe & Ordre & Famille & Espèce & Nombre \\
\hline \multirow{7}{*}{ Arachnida } & \multirow{6}{*}{ Aranea } & \multirow[t]{2}{*}{ Gnaphosidae } & Gnaphosidae sp & 6 \\
\hline & & & Gnaphosidae sp 1 & 1 \\
\hline & & Salticidae & Salticidae $s p$ & 7 \\
\hline & & Linyphidae & Linyphidae $s p$ & 6 \\
\hline & & Lycosidae & Lycosidae $\mathrm{sp}$ & 6 \\
\hline & & Thomisidae & Thomisidae sp & 2 \\
\hline & Acarien & Acaridae & Acari $s p$ & 2 \\
\hline \multirow[t]{2}{*}{ Collembola } & \multirow[t]{2}{*}{ Entomobryomorpha } & \multirow[t]{2}{*}{ Entomobrydae } & Entomobrydae sp & 2 \\
\hline & & & Entomobrydae sp 1 & 1 \\
\hline Crustacea & Isopoda & Oniscidae & Oniscidae sp & 1 \\
\hline \multirow{10}{*}{ Insecta } & \multirow{3}{*}{ Thysanoptera } & \multirow{3}{*}{ Famille indet. } & Thysanoptera sp & 7 \\
\hline & & & Thrips $s p$ & 1 \\
\hline & & & Thysanoptera sp 1 & 2 \\
\hline & \multirow{7}{*}{ Orthoptera } & \multirow[t]{5}{*}{ Gryllidae } & Gryllomorpha sp & 8 \\
\hline & & & Gryllulus algerius & 1 \\
\hline & & & Gryllulus $s p$ & 2 \\
\hline & & & Gryllulus sp1 & 1 \\
\hline & & & Gryllulus sp2 & 1 \\
\hline & & \multirow[t]{2}{*}{ Pyrgomrphidae } & $\begin{array}{c}\text { Pyrgomorpha cognata } \\
\text { (Krauss, 1877) }\end{array}$ & 67 \\
\hline & & & Pyrgomorpha sp & 12 \\
\hline
\end{tabular}




\begin{tabular}{|c|c|c|c|}
\hline & \multirow{4}{*}{ Acrididae } & $\begin{array}{c}\text { Acrotylus patruelis } \\
\text { (Herrich Schaeffer, 1838) }\end{array}$ & 2 \\
\hline & & $\begin{array}{c}\text { Thisoicetrus annulosus } \\
\text { (Walker, F., 1870) }\end{array}$ & 1 \\
\hline & & Acrididae sp & 1 \\
\hline & & Sphingotus sp & 1 \\
\hline Heteroptera & Famille ind & Heteroptera sp & 2 \\
\hline \multirow{7}{*}{ Homoptera } & \multirow[t]{2}{*}{ Aleyrodidae } & Aleurodidae $s p$ & 4 \\
\hline & & Aleurodidae sp 1 & 1 \\
\hline & Aphididae & Aphididae sp & 2 \\
\hline & \multirow[b]{2}{*}{ Cercopidae } & Cercopidae sp & 2 \\
\hline & & Cercopidae sp 1 & 1 \\
\hline & \multirow[b]{2}{*}{ Jassidae } & Jassidae sp & 32 \\
\hline & & Jassidae sp 1 & 6 \\
\hline \multirow{8}{*}{ Coleoptera } & \multirow[t]{2}{*}{ Anthicidae } & Formicomus sp & 4 \\
\hline & & Anthicus sp & 2 \\
\hline & Carabidae & $\begin{array}{l}\text { Microlestes corticalis } \\
\text { (L. Dufour, 1820) }\end{array}$ & 1 \\
\hline & \multirow[t]{4}{*}{ Chrysomelidae } & Chaetocnema sp & 26 \\
\hline & & Chrysomelidae sp 1 & 1 \\
\hline & & Chrysomelidae sp 2 & 1 \\
\hline & & Alticinae $\mathrm{sp}$ & 1 \\
\hline & Coccinellidae & Pullus suturalis & 6 \\
\hline
\end{tabular}




\begin{tabular}{|c|c|c|c|}
\hline & & (Thunberg 1795) & \\
\hline & & $\begin{array}{l}\text { Epilachna argus } \\
\text { (Geoffroy, 1762) }\end{array}$ & 1 \\
\hline & & Coccinellidae sp & 2 \\
\hline & & $\begin{array}{c}\text { Coccinella algerica } \\
\text { (Kovar, 1977) }\end{array}$ & 1 \\
\hline & Curculionidae & Lixus sp & 3 \\
\hline & Dermestidae & Dermestidae sp & 2 \\
\hline & & Anthrenus sp & 1 \\
\hline & Halticinae & Halticinae sp & 2 \\
\hline & Coléoptera & Coléoptera sp ind & 3 \\
\hline & Tenebrionidae & Asida $s p$ & 11 \\
\hline & Scarabaeidae & Scoliidae sp & 1 \\
\hline & Aphelinidae & Aphelinidae sp & 4 \\
\hline & Pompilidae & Pompilidae sp & 3 \\
\hline & & Pompilidae sp 1 & 1 \\
\hline & Halictidae & Evyleus $\mathrm{sp}$ & 1 \\
\hline & & Braconidae sp & 1 \\
\hline Hymenoptera & Braconidae & Braconidae sp 1 & 1 \\
\hline & Bethylidae & Bethylidae sp & 5 \\
\hline & Opomyzidae & Opomysidae sp & 11 \\
\hline & Chalcididae & Chalcidae sp & 4 \\
\hline
\end{tabular}




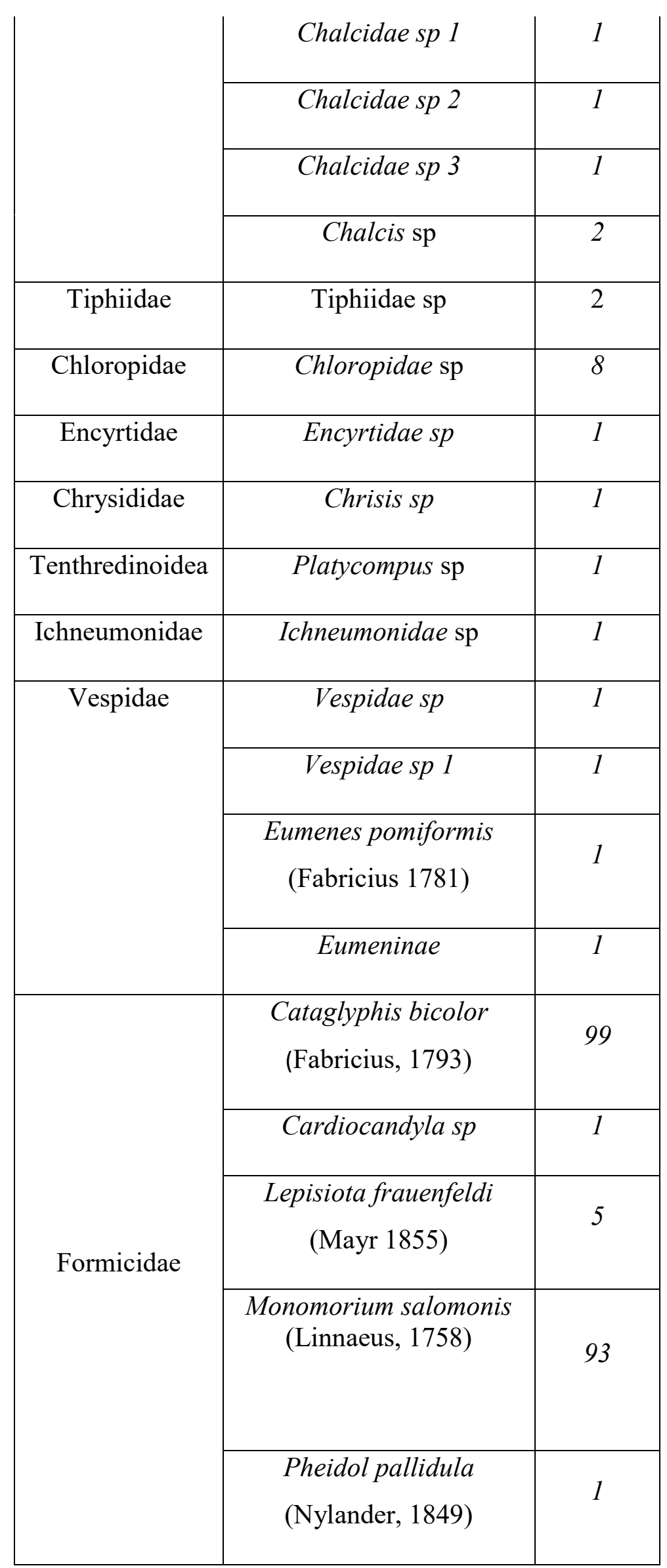




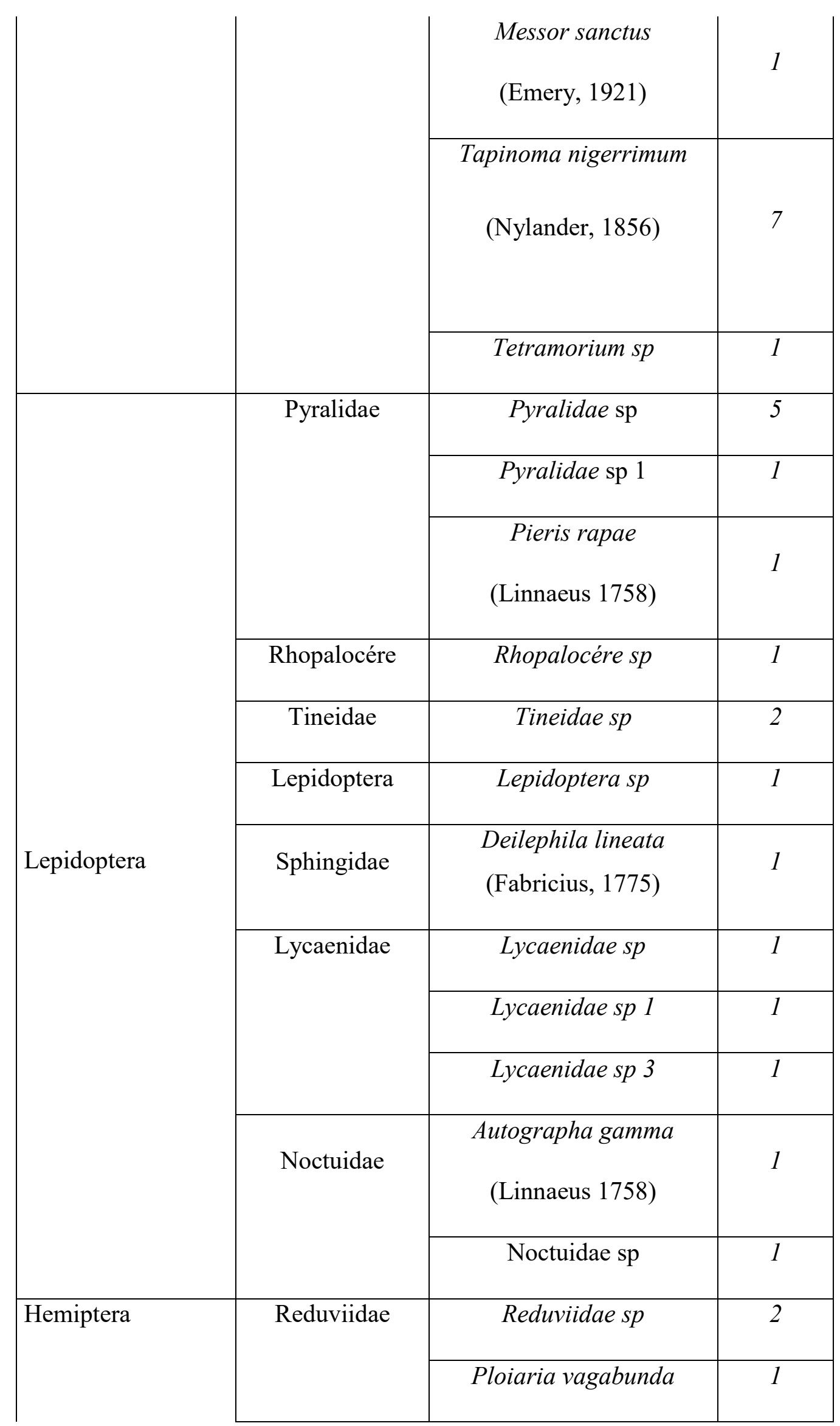




\begin{tabular}{|c|c|c|c|}
\hline & Lygaeidae & Nysus sp & 3 \\
\hline & Pentatomidae & $\begin{array}{c}\text { Carpocoris } \\
\text { purpureipennis } \\
\text { (De Geer, 1773) }\end{array}$ & 1 \\
\hline & & $\begin{array}{l}\text { Eurydema ornata } \\
\text { (Linnaeus, 1758) }\end{array}$ & 1 \\
\hline & Anthomyiidae & Anthomyiinae sp & 1 \\
\hline & Bombyliidae & Bombyliidae sp & 1 \\
\hline & Dolichopodidae & Asyndetus sp & 63 \\
\hline & & Sciapus sp & 3 \\
\hline & Chloropidae & Chloropidae sp & 9 \\
\hline & Chironomidae & Chironomidae sp & 1 \\
\hline & Sarcophagidae & Sarcophaga sp & 1 \\
\hline & Syrphidae & Didea $s p$ & 1 \\
\hline & & Syrphidae sp & 1 \\
\hline & Scatophagidae & Scatophagidae sp & 3 \\
\hline Dinter & & Scatophagidae sp 1 & 1 \\
\hline & & Scatophagidae sp 2 & 1 \\
\hline & Agromyzidae & Agromyzidae sp & 3 \\
\hline & Calliphoridae & $\begin{array}{l}\text { Chrysomya albiceps } \\
\text { (Wiedemann, 1819) }\end{array}$ & 1 \\
\hline & & Callifora $s p$ & 1 \\
\hline & & Lucilia sp & 1 \\
\hline & Phoridae & Phoridae sp & 1 \\
\hline
\end{tabular}




\begin{tabular}{|c|c|c|c|c|}
\hline & & Empididae & Elaphropeza sp & 2 \\
\hline & & & Tachypeza sp & 1 \\
\hline & & Tachynidae & Tachinidae sp & 4 \\
\hline & & Pipunculidae & Pipunculus sp & 1 \\
\hline & & & Pipinculidae sp1 & 1 \\
\hline & & & Cecidomyiidae sp & 7 \\
\hline & & Cecidomyiidae & Cecidomyia sp & 1 \\
\hline & & & Contarinia sp & 14 \\
\hline & & & Muscidae sp & 1 \\
\hline & & Muscidae & $\begin{array}{l}\text { Musca domestica } \\
\text { (Linnaeus, 1758) }\end{array}$ & 5 \\
\hline & & & Muscinae sp & 1 \\
\hline Total : 4 & 13 & 66 & 125 & 685 \\
\hline
\end{tabular}

